\title{
Morphometric and Molecular Study of Fasciola Isolates from Ruminants in Iran
}

İran’da Geviş Getiren Hayvanlarda Fasciola Izolatlarının Morfometrik ve Moleküler Calışması

\author{
Elham Akhlaghi', Mohammad Ali Mohammadi ${ }^{1}$, Naser Ziaali², Mohammad Reza Baneshi \\ Saeid Nasibi ${ }^{1}$, Hossein Kamyabi ${ }^{2}$, Sima Rostami ${ }^{4}$, Majid Fasihi Harandi ${ }^{1}$
}

${ }^{1}$ Research Center for Hydatid Disease in Iran, Kerman University of Medical Sciences, Kerman, Iran

2Department of Parasitology, Kerman University of Medical Sciences, Kerman, İran

${ }^{3}$ Research Center for Modelling in Health, Kerman University of Medical Sciences, Kerman, İran

${ }^{4}$ Dietary Supplements and Probiotics Research Center, Alborz University of Medical Sciences, Karaj, İran

Cite this article as: Akhlaghi E, Mohammadi MA, Ziaali N, Baneshi MR, Nasibi S, Kamyabi H, et al. Morphometric and Molecular Study of Fasciola Isolates from Ruminants in Iran. Türkiye Parazitol Derg 2017; 41: 192-7.

\begin{abstract}
Objective: The purpose of the present study was morphometric and molecular characterization of Fasciola isolates from ruminants in Iran. Methods: Flukes were collected from the livers of 54 naturally infected sheep and cattle. The proportion of body length to width (L/W) of each fresh fluke was measured using a digital caliper. We employed receiver operating characteristic (ROC) curve analysis to explore the reliability of $L / W$ for differentiating the two species. Polymerase chain reaction (PCR)-sequencing was performed on ribosomal Internal Transcribed Spacers (ITS) and mitochondrial cytochrome c oxidase subunit 1 (cox1) genes. The sequences were then analyzed and phylogenetic relationships were investigated.

Result: Forty-eight out of 54 isolates (88.9\%) were identified as F. hepatica and four isolates (7.4\%) as F. gigantica. All the sheep isolates were F. hepatica, while 4 out of 10 cattle were infected with F. gigantica. The morphometric study revealed an L/W ratio of 1.2 to 6.5 in Fasciola isolates with significantly higher L/W ratio in F. gigantica $(p<0.00)$. According to the ROC curve analysis, the $L / W$ value of 3.55 was regarded as the critical value to discriminate between the two species.

Conclusions: Findings of the present study indicate the presence of both Fasciola species in southeastern Iran. The phylogenetic analysis revealed two different clades representing F. hepatica and F. gigantica. The two isolates in this study were described as Fasciola sp. The mitochondrial DNA of these isolates were similar to $F$. hepatica, while their ITS fragments were identical to $F$. gigantica.

Keywords: Fasciola, Morphometry, Iran, cox1, ITS

Received: 05.02.2017

Accepted: 05.10 .2017

Öz

Amaç: Bu çalışmanın amacı İran'daki geviş getiren hayvanlarda Fasciola izolatlarının morfometrik ve moleküler karakterizasyonunu yapmaktır. Yöntemler: Doğal olarak enfekte olan 54 koyun ve sığırın karaciğerinden parazitler alındı. Her canlı parazitin vücut uzunluğunun genişliğine oranı (L/W) dijital kaliper ile ölçüldü. İki türü ayırt etmek için L/W güvenilirliğini bulmak için alıcı işletim karakteristik (ROC) eğrisi kullanıldı. Polimeraz zincir reaksiyon (PZR) dizilimi ribozomal iç transkripsiyonu aralayıcı (ITS) ve mitokondriyal Sitokrom c oksidaz altbirimi 1 (cox1) genlerinde yapıldı. Daha sonra dizilimler analiz edildi ve filogenetik ilişkiler araştırıldı.

Bulgular: Elli dört izolattan 48'inin $(\% 88,9) F$. hepatica ve 4'ünün $(\% 7,4) F$. gigantica olduğu belirlendi. On sığırdan 4'ü F. gigantica ile enfekte olurken, tüm koyun izolatları F. hepatica olarak bulundu. Morfometrik çalışmada, Fasciola izolatlarında 1,2/6,5 olarak tespit edilen L/W oranı, F. gigantica izolatlarından anlamlı ölçüde daha yüksekti. ROC eğrisi analizine göre, 3,55 L/W değeri iki türü ayırt etmek için kritik değer olarak kabul edildi.

Sonuç: Mevcut çalışmanın bulguları güneydoğu Iran'da her iki Fasciola türünün varlığını göstermektedir. Filogenetik analiz $F$. hepatica ve $F$. gigantica'yi gösteren iki farklı türü ortaya koymuştur. Bu çalışmadaki iki izolat Fasciola sp. olarak tanımlandı. ITS fragmentleri F. gigantica ile aynı iken, bu izolatların mitokondriyal DNA'ları F. hepatica'ya benzerdi
\end{abstract}

Anahtar Kelimeler: Fasciola, Morfometri, Iran, cox1, ITS

Geliş Tarihi: 05.02.2017 Kabul Tarihi: 05.10.2017

Address for Correspondence / Yazışma Adresi: Majid Fasihi Harandi, E.mail: majid.fasihi@gmail.com DOI: $10.5152 /$ tpd.2017.5214

(C) Copyright 2017 Turkish Society for Parasitology - Available online at www.tparazitolderg.org

OTelif hakkı 2017 Türkiye Parazitoloji Derneği - Makale metnine www.tparazitolderg.org web sayfasından ulaşılabilir. 


\section{INTRODUCTION}

The two Fasciolid species Fasciola hepatica and F. gigantica are the agents of fasciolosis in animals and humans. The definitive host range of Fasciola is very wide with mainly herbivorous animals as well as several mammalian species including humans. The larval stages of the parasite develop in Lymnaeid snail as intermediate hosts (1).

Human fasciolosis has been reported in many countries worldwide. It is estimated that 2.4 million people in more than 60 countries are infected, and the number of people at risk is more than 180 million throughout the world (1). F. hepatica infects more than 300 million cattle and 250 million sheep worldwide (2).

F. hepatica and F. gigantica causes considerable economic losses to worldwide farming estimated as more than US\$ 3.2 billion annually $(3,4)$. Human fascioliasis was sporadic in Iran until 1987 when an outbreak occurred in the northern province of Gilan and affected more than 10,000 people (5). The second outbreak occurred 10 years later and several thousand people were infected (6). The disease is also endemic in the countries of the region. In Erzurum, Turkey, out of 76 fecal samples collected from horses, $2.6 \%$ were found infected using flotation and sedimentation methods (7). Recent emerging focus of the disease has been documented in Yasuj, southwest of Iran (8).

Information about phenotype and molecular characterization of Fasciola is useful for accurate identification of the etiology of disease as well as for the prevention and control of fascioliasis in each endemic region $(9,10)$. The differentiation between species of Fasciola is important because the intermediate hosts for the two species are different with different ecological and biological characteristics. Additionally, the hybridization phenomenon occurs where both species co-exist. Fasciola forms intermediate between $F$. hepatica and F. gigantica have been reported from Asian countries, including Korea (11), Japan (12), Iran (13), China $(14)$, and Vietnam $(15,16)$ as well as African countries including Egypt $(17,18)$.

Our understanding on the phenotypic and genetic features of Fasciola in southeastern Iran is limited. The purpose of this study was morphometric and genetic description of Fasciola isolates using nuclear and mitochondrial markers by Polymerase chain reaction (PCR) sequencing.

\section{METHODS}

\section{Sample collection and morphometry}

The research proposal has been approved by the Kerman University research of Medical Sciences Ethical Review. Infected livers from sheep and cattle were collected from abattoirs between June 2013 and September 2014. Fifty-four adult Fasciola parasites were collected from the bile ducts of infected cattle and sheep livers. Fresh worms were washed thrice in physiological saline. The flukes were placed on a slide, and body length and width were measured using a digital caliper; thereafter, the flukes were frozen in physiological saline for further molecular studies.

\section{Molecular study}

A small piece of the posterior parts of the flukes were cut and total DNA was extracted from individual flukes using High Pure
PCR template purification kit (Roche, Heidelberg, Germany) according to the manufacturer's instructions. According to previous studies $(12,15)$, partial nuclear Internal Transcribed Spacers (ITS) and mitochondrial cytochrome coxidase subunit 1 (cox1) regions were selected and corresponding primer sets (forward and reverse) were used as follows: ITS1 (660bp) ITS1F: TTGCGCTGATTACGTCCCTG and ITS1R: TTGGCTGCGCTCTTCATCGAC; ITS2 (530bp) 3Sf: GGTACCGGTGGATCACTCGGCTCGTG and BD2R: TATGCTTAAATTCAGCGGGT;.cox1 (500bp) Ita8: ACGTTGGATCATAAGCGTGT and Ita9: CCTCATCCAACATAACCTCT.

DNA fragments of each target region were amplified using PCR. The PCR thermal profiles were as follows: ITS1: $94^{\circ} \mathrm{C}$ for $2 \mathrm{~min}$ (initial denaturation) followed by 30 cycles of $94^{\circ} \mathrm{C}, 30 \mathrm{~s}$ (denaturation), $57^{\circ} \mathrm{C}, 30 \mathrm{~s}$ (annealing), and $72^{\circ} \mathrm{C}, 45 \mathrm{~s}$ (extension); ITS2: $94^{\circ} \mathrm{C}$ for $5 \mathrm{~min}$ (initial denaturation) followed by 30 cycles of $94^{\circ} \mathrm{C}$, $1 \mathrm{~min}$ (denaturation), $50^{\circ} \mathrm{C}, 1 \mathrm{~min}$ (annealing), and $72^{\circ} \mathrm{C}, 1 \mathrm{~min}$ (extension); $\operatorname{cox} 1: 94^{\circ} \mathrm{C}$ for $5 \mathrm{~min}$ (initial denaturation) followed by 30 cycles of $94^{\circ} \mathrm{C}, 1 \mathrm{~min}$ (denaturation), $60^{\circ} \mathrm{C}, 1 \mathrm{~min}$ (annealing), and $72^{\circ} \mathrm{C}, 30 \mathrm{~s}$ (extension).

\section{Sequencing and phylogenetic construction}

The PCR products were sequenced using ABI 3730XL capillary machine (Macrogen Inc., South Korea). The GenBank Blast program was used for ITS and CO1 comparisons. Sequences were analyzed using Bioedit software and aligned with published sequences of different Digenean helminthes using the ClustalW multiple alignment program. The sequences were entered in the $M E G A^{\circledR}$ for constructing phylogenetic trees using the maximum likelihood approach. Branch support was given using 1000 bootstrap replicates in MEGA ${ }^{\circledR}$. Specific identification was confirmed by comparison with known sequences of the corresponding species in GenBank.

\section{Statistical analysis}

A digital caliper was used to calculate the length (L), width (W), and the ratio of $\mathrm{L} / \mathrm{W}$. The mean and standard deviations were calculated for the dataset. For analyzing the significance of difference between morphometric characters, the Student t-test was used with a $p$ value $<0.05$ as a threshold of significance.

Polymerase chain reaction analysis was used to distinguish between F. hepatica and F. gigantica, and the results were considered gold standard. We applied receiver operating characteristic (ROC) curve statistical analysis to explore whether L/W can be used as a surrogate for PCR. In particular, we aimed to determine a cut off with high sensitivity and specificity. We used the Itagaki et al (16) dataset as a test set to assess the external validity of our results. We applied the optimal cut off derived from our data to Itagaki et al (16) dataset. Results are presented in terms of sensitivity and specificity.

\section{RESULTS}

Fifty-four Fasciola isolates from sheep and cattle were collected from three geographical locations, i.e., Kerman (33 sheep and 1 cattle), Jiroft (8 cattle), and Karaj (11 sheep and 1 cattle).

\section{Morphometric findings}

The results of the morphometric study are summarized in Table 1. The range of L/W was 1.2 to 6.5 in Fasciola parasites. According to the molecular study, a significant difference in L/W data 
were documented between F. gigantica (4.1-6.5) and F. hepatica (1.2-2.7; $\mathrm{p}<0.05)$. According to the ROC curve analysis, we found an L/W value of 3.55 as critical to discriminate between the two species (Table 2). Hence, we postulated that all the isolates with an L/W value $>3.55$ are F. gigantica with $100 \%$ sensitivity and specificity. When we applied this cut off to the Itagaki et al (16) dataset, sensitivity and specificity values were $90 \%$ and $85 \%$, respectively. As shown in Table 1, a significant difference in the body length and width as well as L/W was recorded between the two species of Fasciola $(p<0.05)$.

\section{Molecular findings}

Molecular analyses revealed that 48 and 4 isolates of Fasciola had the sequences identical to F. hepatica and F. gigantica. The molecular analysis of the isolates showed 11,6, and 3 haplotypes for mitochondrial, ITS1 and ITS2 regions, respectively. Phylogenetic rDNA analysis of the specimens showed two sister clades representing F. hepatica (ITS-Fh) and F. gigantica (ITS-Fg). The phylogenetic analysis revealed two different clades representing

Table 1. Morphometric characters of adult Fasciola isolates from ruminants in Iran

\begin{tabular}{|c|c|c|c|}
\hline & $\begin{array}{c}\text { Length (L), mm } \\
\text { Range } \\
\text { (mean } \pm S D \text { ) }\end{array}$ & $\begin{array}{c}\text { Width }(\mathrm{W}), \mathrm{mm} \\
\text { Range } \\
\text { (mean } \pm \text { SD) }\end{array}$ & $\begin{array}{c}\text { L/W } \\
\text { Range } \\
\text { (mean士SD) }\end{array}$ \\
\hline F. hepatica & $\begin{array}{c}4-30.2 \\
(20.1 \pm 4.6)\end{array}$ & $\begin{array}{l}3.7-13.8 \\
(9.8 \pm 1.9)\end{array}$ & $\begin{array}{c}1.2-2.7 \\
(2.0 \pm 0.42)\end{array}$ \\
\hline F. gigantic & $\begin{array}{c}6.8-27.9 \\
(36.2 \pm 4.3)\end{array}$ & $\begin{array}{c}5.5-7.1 \\
(6.5 \pm 0.73)\end{array}$ & $\begin{array}{c}4.1-6.5 \\
(5.4 \pm 0.99)\end{array}$ \\
\hline Fasciola sp & $\begin{array}{c}8.4-27.1 \\
(2.7 \pm 0.91)\end{array}$ & $\begin{array}{c}9.2-10.6 \\
(9.9 \pm 0.98)\end{array}$ & $\begin{array}{c}2.9-3 \\
(2.9 \pm 0.014)\end{array}$ \\
\hline
\end{tabular}

F. hepatica and F. gigantica (Figure 1,2). The two isolates in this study were described as Fasciola sp. The mitochondrial DNA of these isolates were similar to F. hepatica, while their ITS fragments were identical to F. gigantica.

\section{DISCUSSION}

Data on the genetic characteristics of Fasciola species in the southeast of Iran are limited. In the present study, adult specimens of Fasciola infecting sheep and cattle from different localities were characterized by sequencing rDNA ITS regions as well as mitochondrial cox1 genes. In addition, the morphometric features of the isolates were studied.

The ratio of body length and width (BL/BW) has been considered one of the practical criteria for discrimination between $F$. hepatica and F. gigantica (17). In the present study, the L/W ratio was proved as a sensitive and specific index for discriminating F. hepatica and F. gigantica isolates. We used the Itagaki et al (16) dataset based on molecular tools to test our morphometric model in a set of Fasciola isolates that were positively identified by rDNA as well as mitochondrial sequencing. The ROC curve analysis was conducted for the first time to find a discrimination threshold with the highest sensitivity and specificity for distinguishing Fasciola species. Most morphometric data have not been tested on an independent dataset. In the present study, the external validity of the threshold has been independently calculated based on the Itagaki et al (16) dataset. The threshold of 3.55 was perfectly matched on both datasets using ROC curve modeling with an adequate sensitivity and specificity of $90 \%$ and $85 \%$, respectively. This indicates that all the isolates with an L/W value of $>3.55$ are F. gigantica.

Table 2. Sensitivity and specificity values of the length to width (L/W) ratio of adult Fasciola isolates for discriminating $F$. hepatica and F. gigantica using receiver operating characteristic (ROC) curve analysis. The optimal threshold for sensitivity and specificity of L/W was assessed. Maximum sensitivity and specificity values were obtained at a threshold of 3.55

\begin{tabular}{|l|c|c|c|c|c|}
\hline L/W & Sensitivity & 1 - Specificity & L/W & Sensitivity & 1 - Specificity \\
\hline .000 & 1.000 & 1.000 & 2.285 & 1.000 & .420 \\
\hline 1.100 & 1.000 & .980 & 2.310 & 1.000 & .300 \\
\hline 1.250 & 1.000 & .960 & 2.345 & 1.000 & .280 \\
\hline 1.350 & 1.000 & .900 & 2.385 & 1.000 & .260 \\
\hline 1.450 & 1.000 & .880 & 2.435 & 1.000 & .220 \\
\hline 1.505 & 1.000 & .860 & 2.485 & 1.000 & .200 \\
\hline 1.555 & 1.000 & .840 & 2.535 & 1.000 & .000 \\
\hline 1.650 & 1.000 & .820 & 2.635 & 1.000 & .060 \\
\hline 1.750 & 1.000 & .780 & 2.720 & 1.000 & .040 \\
\hline 1.815 & 1.000 & .720 & 2.820 & 1.000 & .020 \\
\hline 1.865 & 1.000 & .700 & 2.950 & 1.000 & .000 \\
\hline 1.950 & 1.000 & .640 & 3.550 & 1.000 & .000 \\
\hline 2.030 & 1.000 & .580 & 4.750 & .750 & .000 \\
\hline 2.080 & 1.000 & .560 & 5.550 & .500 & .000 \\
\hline 2.155 & 1.000 & .480 & 6.100 & .250 & .000 \\
\hline 2.230 & 1.000 & .460 & 7.500 & .000 & \\
\hline 2.260 & 1.000 & .440 & & & \\
\hline
\end{tabular}




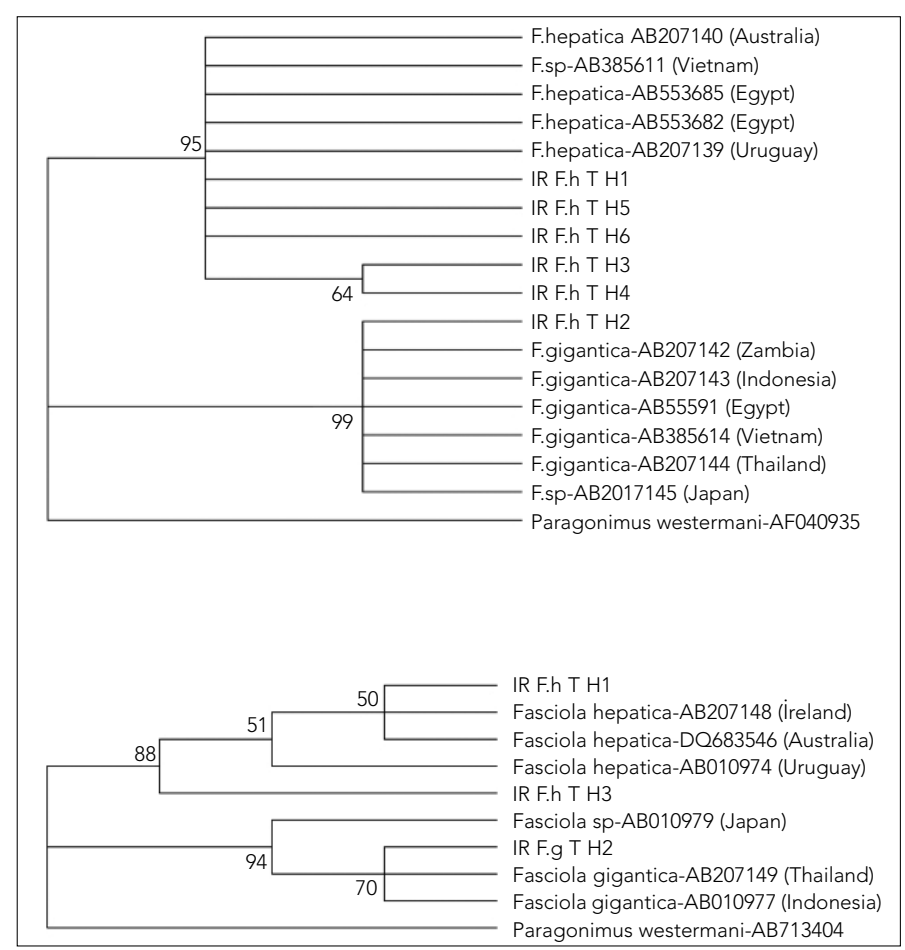

Figure 1. Genetic relationships of Fasciola species from ruminants in Iran and reference species (F. gigantica, F. hepatica, and Fasciola sp.) from previous studies based on nuclear ITS-1 (upper) and ITS2 (lower) markers were estimated using the maximum likelihood approach. Phylogenetic trees were obtained using MEGA 4.0 with bootstrap values of 1000 replicates set for maximum likelihood. There were six haplotypes for ITS1 region including H1 (KT921263-KT921265), H2 (KT921274, KT921278), H3 (KT921266), H4 (KT921267), H5 (KT921268), and H6 (KT9 21269) and three haplotypes for ITS2, including H1 (KT921270-KT921272), H2 (KT921275), and H3 (KT921273)

Based on the molecular results, $88.9 \%$ and $7.4 \%$ of the isolates were identified as F. hepatica and F. gigantica, respectively. F. hepatica has been the dominant species responsible for fascioliasis in ruminants in the world. Studies in Iran have shown that $F$. hepatica and F. gigantica are more prevalent in sheep and cattle, respectively. Recent studies in Iran showed that 15 out of 45 (33.3\%) cattle isolates were F. gigantica compared to only $11.1 \%$ of 45 sheep isolates (19). Rokni et al (20) showed that 30 out of 31 sheep (96.8\%) were F. hepatica. One study in Niger showed $66.7 \%$ of 12 cattle isolates were F. gigantica (21). In Tanzania, all the Fasciola isolates from 41 sheep were F. hepatica (22). Another study in Spain showed all of the isolates from cattle were $F$. hepatica (23). In the present study, none of the 44 sheep isolates were F. gigantica implicating a host preference of this species toward cattle.

Two isolates have been reported as Fasciola sp. in this study. The intermediate forms of Fasciola have been reported from Asian countries, including Japan, Vietnam, Korea, and China. Mitochondrial DNA sequence analysis of two isolates showed identical results with F. hepatica; however, rDNA sequencing identified them as F. gigantica. These results were in strong agreement with the morphometric results. The length to width analysis of 48 isolates sequenced as $F$. hepatica showed an average ratio of 2, while four F. gigantica isolates showed a mean value of 5.4. The

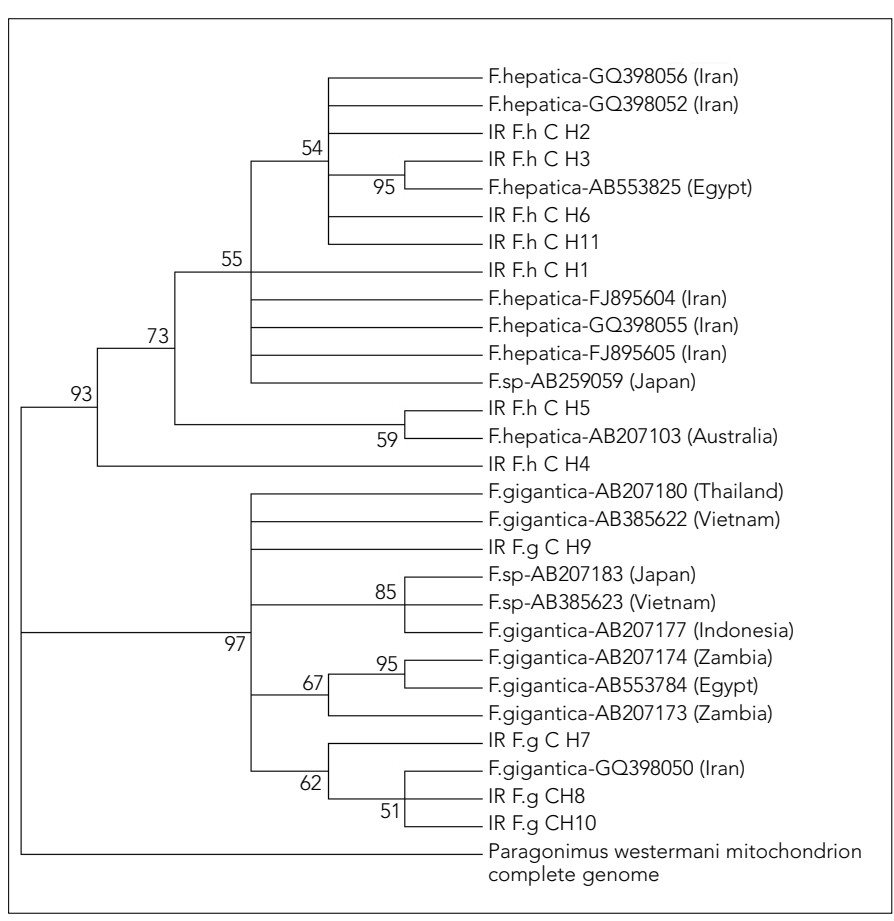

Figure 2. Genetic relationships of Fasciola species from ruminants in Iran and reference species (F. gigantica, F. hepatica, and Fasciola spp.) from previous studies based on cox1 gene marker estimated using the maximum likelihood approach. Phylogenetic trees were obtained using MEGA 4.0 with bootstrap values of 1000 replicates set for maximum likelihood. There were 11 haplotypes for cox1 region, including $\mathrm{H} 1$ (KT893716-KT893717), H2 (KT893718-KT893720), H3 (KT893721KT893722), H4 (KT921276), H5 (KT893723), H6 (KT893724), H7 (KT893712), H8 (KT893713), H9 (KT893714), H10 (KT893715), and H11 (KT893725)

corresponding L/W value for the two Fasciola sp. isolates was 2.9. These results are consistent with those of a study by Nguyen et al (2) wherein the ratio ranges of L/W values were 1.29-2.80 in F. hepatica and 3.4-6.8 in F. gigantica (2). Watanabe (24) reported $\mathrm{L} / \mathrm{W}$ as 2 in F. hepatica and $>3$ in F. gigantica. An intermediate $\mathrm{L} / \mathrm{W}$ ratio of $3.1 \pm 0.5$ was reported in aspermic triploid Fasciola specimens from Japan (25). According to this finding, the two Fasciola sp. isolates of the present study may be considered as hybrid forms of F. hepatica/F. gigantica.

As shown in other studies, the level of diversity in mitochondrial cox1 was significantly higher than that in the nuclear ITS (26). In the present study, eleven cox1 haplotypes were found, while 6 ITS1 and 3 ITS2 haplotypes were identified in 54 isolates. It has been previously documented that the ITS regions are more conserved than the mitochondrial regions (18).

The molecular analysis showed 7 haplotypes within 50 isolates of $F$. hepatica and 4 haplotypes in 4 isolates of F. gigantica. Amer et al (18) found 19 haplotypes in 31 F. gigantica isolates, while 14 haplotypes were found in $34 \mathrm{~F}$. hepatica isolates. The findings indicated that the genetic variation within F. gigantica is higher than that in F. hepatica in mitochondrial regions (18). The size of cattle liver, larger diameter of bile ducts, intensity of infection in cattle, and the number of the parasites in the bovine hepatic bile 
ducts may contribute to greater genetic exchange and higher intraspecific variation within F. gigantica in cattle.

Two different clades were produced using phylogenetic analysis of cox1 gene representing F. hepatica and F. gigantica. The dendrogram topology showed that the two species split apart (Figure 2). The isolates were divided into three sister clusters in F. hepatica and two clusters in F. gigantica. The two Fasciola sp. isolates were located between the two species with more resemblance to $F$. hepatica isolates in a same clade with an intermediate form of Fasciola sp. from Japan (27). The haplotypes 2, 6, and 3 were remarkably similar to $F$. hepatica isolates from the northern province of Gilan (28) and from Egypt (18). The haplotypes 7,8 , and 10 have shown to be clustered with cattle isolates of $F$. gigantica from the southwestern city of Ahvaz (28).

The phylogenetic analysis of the ITS regions produced a well-defined dendrogram representing two distinct clades for $F$. hepatica and F. gigantica isolates. ITS-1 haplotypes 1, 3, 4, 5, and 6 were remarkably similar to F. hepatica isolates from Egypt (18), Uruguay, and Australia (29). Two out of three isolates within haplotype 2 have shown to be Fasciola sp. and located in a same cluster with Fasciola spp from Japan (29) and F. gigantica from Zambia, Indonesia and Thailand, Egypt (18), and Vietnam (16).

\section{CONCLUSION}

Accurate identification of Fasciola species is fundamental to any control measures. Information provided in this study indicated the presence of both Fasciola species as well as the intermediate forms in southeastern Iran. However, more molecular investigations are required on a wider variety of isolates from different host species and geographical locations. The background information for more comprehensive molecular and morphological studies on fascioliasis in the region has been provided in the present study.

Ethics Committee Approval: Ethics committee approval was received from Kerman Universitesi, Medical Faculty of the Ethics Committee.

Informed Consent: Not required in this study.

Peer-review: Externally peer-reviewed.

Author Contributions: Concept - M.F.H, E.A, S.R., N.Z., S.S..; Design M.F.H., M.A.M., M.R.B., E.A.; Supervision - M.F.H., N.Z., H.K., S.N., S.R.; Funding - M.F.H., M.A.M., H.K., S.N.; Materials - H.K., M.A.M., S.R.; Data Collection and/or Processing - E.A., M.F.H., M.R.B., M.A.M.,; Analysis and/or Interpretation - M.F.H., M.R.B., N.Z., S.N., M.A.M., E.A.; Literature Review - E.A., M.A.M.; Writing - E.A., M.A.M., N.Z., M.R.B., S.N., H.K., S.R., M.F.H.; Critical Review - E.A., M.R.B., M.F.H.;

\section{Conflict of Interest: None.}

Financial Disclosure: The study was financially supported by a grant from the University Vice-Chancellor for Research and Technology (No. 92-133).

Etik Komite Onayı: Bu çalışma için etik komite onayı Kerman Üniversitesi, Tıp Fakültesi Etik Kurul'undan alınmıştır

Hasta Onamı: Bu çalışma için hasta onamına gerek yoktur.

Hakem Değerlendirmesi: Dış bağımsız.
Yazar Katkıları: Fikir - M.F.H, E.A, S.R., N.Z., S.S.; Tasarım - M.F.H., M.A.M., M.R.B., E.A.; Denetleme - M.F.H., N.Z., H.K., S.N., S.R.; Veri Toplanması ve/veya İşlemesi - E.A., M.F.H., M.R.B., M.A.M.; Analiz ve/veya Yorum - M.F.H., M.R.B., N.Z., S.N., M.A.M., E.A.; Literatür Taraması - E.A., M.A.M.; Yazıyı Yazan - E.A., M.A.M., N.Z., M.R.B., S.N., H.K., S.R., M.F.H.; Eleştirel İnceleme - E.A., M.R.B., M.F.H.

Çıkar Çatışması: Yazarlar çıkar çatışması bildirmemişlerdir.

Finansal Destek: Bu çalışma, Üniversitenin Araştırma ve Teknoloji Asistanı tarafından desteklenmiştir (No. 92-133).

\section{REFERENCES}

1. Mas-Coma MSM, Esteban JGJ, Bargues MDM. Epidemiology of human fascioliasis: A review and proposed new classification. Bull World Health Organ 1999; 77: 340-6.

2. Nguyen S, Amer S, Ichikawa M, Itagaki T, Fukuda Y, Nakai Y. Molecular identification of Fasciola spp. (Digenea: Platyhelminthes) in cattle from Vietnam. Parasite 2012; 19: 85-9. [CrossRef]

3. Mas-Coma S, Bargues MD, Valero MA. Fascioliasis and other plant-borne trematode zoonoses. Int J Parasitol 2005; 35: 1255-78. [CrossRef]

4. Charlier J, Duchateau L, Claerebout E, Williams D, Vercruysse J. Associations between anti-Fasciola hepatica antibody levels in bulktank milk samples and production parameters in dairy herds. Prev Vet Med 2007; 78: 57-66. [CrossRef]

5. Massoud J. Fascioliasis outbreak of man and drug test (Triclabendazole) in Caspian Sea Littoral, northern part of Iran. Bull Soc Parasitol 1990; 8: 438-9.

6. Forghan-Parast K, Ashrafi K. Comparison of the formalin-ether and Kato-Katz in the parasitological diagnosis of human fascioliasis. $J$ Med Fac Gilan Univ Med Sci 2001; 9: 1-6.

7. Avcioglu H, Guven E, Balkaya I, Yavuz S, Abay U, Akyuz M, et al. Parasites Determined by Fecal Examination in Horses in Erzurum. Turkiye Parazitol Derg 2016; 40: 147-51. [CrossRef]

8. Sarkari B, Ghobakhloo N, Moshfea A, Eilami O. Seroprevalence of human fasciolosis in a new-emerging focus of fasciolosis in Yasuj district, southwest of Iran. Iran J Parasitol 2012; 7: 15-20.

9. Kuk S, Erensoy A. Gene cloning, selection of plasmids and application of Fasciola hepatica cathepsin L1 gen. Turkiye Parazitol Derg 2007; 32: 16-22.

10. Kaya M, Bestas R, Çiçek M, Önder A, Kaplan MA. The Value of micro-ELISA Test in the Diagnosis of Fasciola hepatica Infection. Turkiye Parazitol Derg 2013; 37: 23-7. [CrossRef]

11. Agatsuma $T$, Arakawa $Y$, Iwagami M, Honzako $Y$, Cahyaningsih U, Kang S-Y, et al. Molecular evidence of natural hybridization between Fasciola hepatica and F. gigantica. Parasitol Int 2000; 49: 231-8. [CrossRef]

12. T. Itagaki T, Kikawa M, Sakaguchi K, Shimo J, Terasaki K, Shibahara T, et al. Genetic characterization of parthenogenic Fasciola sp. in Japan on the basis of the sequences of ribosomal and mitochondrial DNA. Parasitology 2005; 131: 679-85. [CrossRef]

13. Amor N, Halajian A, Farjallah S, Merella P, Said K, Slimane B Ben. Molecular characterization of Fasciola spp. from the endemic area of northern Iran based on nuclear ribosomal DNA sequences. Exp Parasitol 2011; 128: 196-204. [CrossRef]

14. Peng M, Ichinomiya $M$, Ohtori M, Ichikawa M, Shibahara T, Itagaki T. Molecular characterization of Fasciola hepatica, Fasciola gigantica, and aspermic Fasciola sp. in China based on nuclear and mitochondrial DNA. Parasitol Res 2009; 105: 809-15. [CrossRef]

15. Le TH, Van De N, Agatsuma T, Nguyen TGT, Nguyen QD, McManus DP, et al. Human fascioliasis and the presence of hybrid/introgressed 
forms of Fasciola hepatica and Fasciola gigantica in Vietnam. Int J Parasitol 2008; 38: 725-30. [CrossRef]

16. Itagaki T, Sakaguchi K, Terasaki K, Sasaki O, Yoshihara S, Van Dung T. Occurrence of spermic diploid and aspermic triploid forms of Fasciola in Vietnam and their molecular characterization based on nuclear and mitochondrial DNA. Parasitol Int 2009; 58: 81-5. [CrossRef]

17. Periago M V, Valero MA, El Sayed M, Ashrafi K, El Wakeel A, Mohamed MY, et al. First phenotypic description of Fasciola hepatica/ Fasciola gigantica intermediate forms from the human endemic area of the Nile Delta, Egypt. Infect Genet Evol 2008; 8: 51-8. [CrossRef]

18. Amer S, Dar Y, Ichikawa M, Fukuda Y, Tada C, Itagaki T, et al. Identification of Fasciola species isolated from Egypt based on sequence analysis of genomic (ITS1 and ITS2) and mitochondrial (NDI and COI) gene markers. Parasitol Int 2011; 60: 5-12. [CrossRef]

19. Mahami-Oskouei M, Dalimi A, Forouzandeh-Moghadam M, Rokni MB. Molecular identification and differentiation of Fasciola isolates using PCR-RFLP method based on internal transcribed spacer (ITS1, 5.8 S rDNA, ITS2). Iran J Parasitol 2011; 6: 35-42.

20. Rokni MB, Mirhendi H, Mizani A, Mohebali M, Sharbatkhori M, Kia EB, et al. Identification and differentiation of Fasciola hepatica and Fasciola gigantica using a simple PCR-restriction enzyme method. Exp Parasitol 2010; 124: 209-13. [CrossRef]

21. Ali H, Ai L, Song HQ, Ali S, Lin RQ, Seyni B, et al. Genetic characterization of Fasciola samples from different host species and geographical localities revealed the existence of $F$. hepatica and $F$. gigantica in Niger. Parasitol Res 2008; 102: 1021-4. [CrossRef]
22. Farjallah S, Sanna D, Amor N, Mehel B Ben, Piras MC, Merella P, et al. Genetic characterization of Fasciola hepatica from Tunisia and Algeria based on mitochondrial and nuclear DNA sequences. Parasitol Res 2009; 105: 1617-21. [CrossRef]

23. Alasaad S, Huang CQ, Li QY, Granados JE, García-Romero C, Pérez $\mathrm{JM}$, et al. Characterization of Fasciola samples from different host species and geographical localities in Spain by sequences of internal transcribed spacers of rDNA. Parasitol Res 2007; 101: 1245-50. [CrossRef]

24. Watanabe S. General review on fascioliasis hepatica in Japan. J Japan Vet Med Assoc. 1958; 11: 293-99. [CrossRef]

25. Terasaki K, Noda Y, Shibahara T, Itagaki T. Morphological comparisons and hypotheses on the origin of polyploids in parthenogenetic Fasciola sp. J Parasitol 2000; 86: 724-9. [CrossRef]

26. Bowles J, Hope M, Tiu WU, Liu X, McManus DP. Nuclear and mitochondrial genetic markers highly conserved between Chinese and Philippine Schistosoma japonicum. Acta Trop 1993; 55: 217-29. [CrossRef]

27. Inoue K, Kanemasa H, Inoue K, Matsumoto M, Kajita Y, Mitsufuji S, et al. A case of human fasciolosis: discrepancy between egg size and genotype of Fasciola sp. Parasitol Res 2007; 100: 665-7. [CrossRef]

28. Sharifiyazdi H, Moazeni M, Rabbani F. Molecular characterization of human Fasciola samples in Gilan province, Northern Iran on the basis of DNA sequences of ribosomal and mitochondrial DNA genes. Comp Clin Path 2011; 21: 889-94. [CrossRef]

29. Itagaki T, Kikawa M, Terasaki K, Shibahara T, Fukuda K. Molecular characterization of parthenogenic Fasciola sp. in Korea on the basis of DNA sequences of ribosomal ITS1 and mitochondrial NDI gene. J Vet Med Sci 2005; 67: 1115-8.[CrossRef] 